\title{
TERAPI MALARIA PADA ANAK
}

\author{
Novi H. Rampengan
}

\author{
Bagian Ilmu Kesehatan Anak Fakultas Kedokteran Universitas Sam Ratulangi Manado \\ Email: novierampengan@yahoo.com
}

\begin{abstract}
Malaria is still a health problem in Indonesia because it is endemic in considerable parts of Indonesia. According to Riskesdas 2010, the most frequent causes of malaria were $P$. falciparum (86.4\%) and P. vivax (6.9\%), with mortality in all age groups increased more than 2 times in 2006-2009 compared to years before. One of the reasons is the increase of malaria parasite resistence to malaria treatment. Therefore, WHO and Ministry of Health in Indonesia recommend that malaria treatment must be by evidence of malaria infection with laboratory tests and malaria medicine must be in combination form to prevent the occurence of resistence. The first line treatment for uncomplicated malaria cases is DHP and AAQ meanwhile the second line is quinine and doxycycline. Moreover, the first line treatment for severe malaria cases is artesunate IV or artemeter IM and the second line is kinine IV.
\end{abstract}

Keywords: plasmodium, malaria, uncomplicated malaria, severe malaria, combination therapy

\begin{abstract}
Abstrak: Malaria masih merupakan masalah di Indonesia karena terdapat endemis di sebagian besar wilayah Indonesia. Menurut Riskesdas tahun 2010 penyebab malaria yang tertinggi ialah $P$. falciparum (86,4\%) dan P. vivax (6,9\%) dengan angka kematian untuk semua kelompok umur meningkat $>2$ kali lipat pada tahun 2006-2009 dibandingkan tahun sebelumnya. Salah satu penyebabnya yaitu meningkatnya resistensi parasit malaria terhadap obat-obat malaria sehingga WHO dan Kemkes merekomendasikan bukti laboratorium terinfeksi malaria dan pemberian obat anti malaria diberikan kombinasi untuk mencegah resistensi. Lini I obat untuk terapi malaria tanpa komplikasi yaitu DHP, AAQ dan lini II kinin + doksisiklin, sedangkan lini I obat untuk terapi malaria berat yaitu artesunat IV atau artemeter IM dan lini II kinin IV.
\end{abstract}

Kata kunci: plasmodium, malaria, malaria tanpa komplikasi, malaria berat, terapi kombinasi

World Health Organization (WHO) melaporkan bahwa di tahun 2010 diperkirakan 3,3 milyar penduduk berisiko terinfeksi malaria. Sekitar 2,1 milyar penduduk berada di risiko rendah $(<1$ kasus per 1000 penduduk) dimana 94\% secara geografik tinggal di luar Afrika dan 1,2 milyar penduduk berada di risiko tinggi (>1 kasus per 1000 penduduk) dengan 47\% tinggal di Afrika dan $37 \%$ di Asia Tenggara. Tahun 2010 diperkirakan terdapat 216 juta kasus malaria dan $81 \%$ berada di Afrika dan $13 \%$ di Asia Tenggara, dengan perkiraan angka kematian 655.000 penduduk dan 91\% kematian terdapat di Afrika. Sekitar 86\% kematian akibat malaria terjadi pada anak usia $<5$ tahun. ${ }^{1-6}$

Malaria merupakan masalah kesehatan masyarakat di Indonesia karena masih endemis di sebagian besar wilayah Indonesia, sehingga dimasukkan sebagai salah satu indikator millennium developmental global (MDGs) dengan target menghentikan penyebaran dan mengurangi kejadian insiden malaria pada tahun 2015 yang dilihat dari indikator menurunnya angka kesakitan dan angka kematian akibat malaria. ${ }^{7}$ Berdasarkan annual parasite incidence (API) dilakukan stratifikasi wilayah dimana Indonesia bagian Timur masuk dalam stratifikasi 
malaria tinggi, stratifikasi sedang di beberapa wilayah di Kalimantan, Sulawesi, dan Sumatera sedangkan Jawa-Bali masuk dalam stratifikasi rendah, meskipun masih terdapat beberapa desa dengan angka terinfeksi malaria yang tinggi. Menurut Riskesdas tahun 2010 penyebab malaria yang tertinggi ialah $P$. falciparum $(86,4 \%)$ dan $P$. vivax (6,9\%) dengan angka kematian untuk semua kelompok umur menurun drastis, dimana pada tahun 2004 angka kematian sebesar $10,51 \%$ menjadi 1,34\% pada tahun 2006, namun angka kematian meningkat $>2$ kali lipat pada tahun 2006-2009.

Meningkatnya angka kematian tersebut dapat disebabkan adanya perubahan lingkungan yang mengakibatkan tempat perindukan nyamuk semakin bertambah, diagnosis malaria yang kurang tepat dan terlambat, meningkatnya resistensi insektisida terhadap vektor, meningkatnya resistensi parasit malaria terhadap obatobat malaria, dan belum tersedianya vaksin malaria. Untuk menghadapi hal tersebut maka WHO merekomendasikan bahwa semua orang di segala usia yang secara epidemiologis tersangka malaria harus melakukan konfirmasi parasitologis diagnosis malaria baik dengan pemeriksaan mikroskopis atau rapid diagnostic test (RDT)/simple immunochromatographic tests, sehingga obat anti malaria tidak boleh dikonsumsi oleh orang dengan diagnosis klinis malaria dan obat malaria yang ada diberikan secara kombinasi untuk mencegah dan mengurangi terjadinya resistensi. ${ }^{8}$

\section{PENGOBATAN MALARIA}

Hal-hal yang perlu diperhatikan dalam pengobatan malaria menurut pedoman pengobatan malaria yang direkomendasikan oleh WHO yaitu: ${ }^{4,9}$

1. Konfirmasi parasitologis yang tepat dengan pemeriksaan mikroskopis, atau alternatif lain dengan RDTs bagi seluruh pasien dengan curiga malaria sebelum memulai terapi. Pengobatan malaria semata-mata berdasarkan kecurigaan klinis hanya dilakukan saat benar-benar tidak tersedia akses pemeriksaan parasitologis untuk diagnosis. Pengobatan berdasarkan diagnostic test yang tepat merupakan penanganan yang baik dan memiliki berbagai keuntungan seperti:

- Perbaikan penanganan pasien yang parasitologis positif karena adanya konfirmasi infeksi terlebih dahulu

- Identifikasi pasien dengan parasitologis negatif sehingga pasien dapat didiagnosis dan diberikan terapi yang sesuai.

- Terhindarnya penggunaan anti malaria pada pasien parasitologis negatif sehingga mengurangi efek samping, interaksi obat, resistensi obat, serta penghematan biaya

- Kepercayaan publik yang lebih baik pada efikasi artesunate combination therapy (ACT) ketika digunakan untuk mengobati kasus pasti malaria.

- Kepercayaan publik yang lebih baik pada diagnosis dan pengobatan kasus-kasus demam non malaria

2. Malaria falsiparum tanpa komplikasi seharusnya diterapi dengan ACT. Primakuin dosis tunggal diberikan sebagai anti gametosit pada malaria falsiparum dengan memperhatikan pasien yang defisiensi G6PD.

3. Malaria vivax seharusnya diterapi dengan klorokuin bila pada wilayah tersebut masih efektif; ACT yang sesuai (bukan artesunat+sulfadoksinpirimetamin) seharusnya digunakan untuk malaria vivax pada wilayah yang terbukti resisten klorokuin. Baik klorokuin dan ACT seharusnya diberikan dengan 14 hari pemberian primakuin untuk mencegah relaps (memperhatikan pasien dengan defisiensi G6PD).

4. Terdapat 5 jenis ACT yang direkomendasikan saat ini yaitu artemeter + lumefantrin, artesunat + amodiakuin, artesunat + meflokuin, 
artesunat + sulfadoksin-pirimetamin, dan dihidroartemisinin + piperakuin (DHP). Pemilihan ACT seharusnya didasarkan pada efikasi kombinasi di tiap-tiap negara.

5. Artemisinin dan derivatnya seharusnya tidak digunakan sebagai monoterapi oral pada pengobatan malaria tanpa komplikasi.

6. Malaria berat seharusnya diterapi dengan artesunat parenteral dan diikuti oleh regimen terapi ACT yang lengkap secepat mungkin penderita dapat meminum obat. Ketika penderita malaria berat tidak dapat diobati secara parenteral, maka pasien harus diterapi sebelum dirujuk kemudian dirujuk sesegara mungkin ke fasilitas yang lebih memadai untuk pengobatan lanjut. Pengobatan sebelum rujukan yaitu artesunat rektal, artesunat intramuskular (IM) atau artemeter IM dan kuinin IM.

\section{OBAT-OBATAN UNTUK TERAPI MALARIA PADA ANAK}

\section{Artemisinin dan derivatnya}

\section{Artemisinin}

Artemisinin merupakan penghancur skizon darah yang poten, cepat dan aktif melawan semua spesies plasmodium malaria. Obat ini memiliki aktivitas luas melawan parasit aseksual dan membunuh semua stadium mulai dari ring muda sampai skizon. Pada malaria falsiparum, artemisinin juga mematikan 4 stadium gametosit yang biasanya hanya sensitif terhadap primakuin. Artemisinin dan derivatnya bekerja dengan menghambat kalsium adenosin trifosfat esensial, PfATPase 6. Konsentrasi puncak plasma terjadi sekitar 3 jam sesudah per oral dan 11 jam sesudah pemberian rektal dengan waktu paruh eliminasi 1 jam. Artemisinin dikonversi menjadi metabolit inaktif melalui enzim sitokrom P450 CYP2B6 dan enzim lainnya. ${ }^{10,11}$ Artemisinin merupakan induktor yang poten dalam metabolismenya sendiri.

Artemisinin dan derivatnya aman dan diketahui toleransi baik. Efek samping yang serius ialah reaksi hipersensitivitas tipe 1 (1:3000). Artemisinin harus dihindari pada ibu hamil trimester pertama dengan malaria tanpa komplikasi karena belum terbukti aman. Obat ini harus diberikan secara kombinasi, untuk mencegah resistensi. Dosis $10 \mathrm{mg} / \mathrm{kgbb}$ per dosis, 2 kali sehari pada hari pertama dilanjutkan 10 $\mathrm{mg} / \mathrm{kgbb}$ dosis tunggal pada 4 hari berikutnya. Tablet dan kapsulnya mengandung $250 \mathrm{mg}$ artemisinin serta supositoria mengandung $100 \mathrm{mg}, 200 \mathrm{mg}$, $300 \mathrm{mg}, 400 \mathrm{mg}$, dan $500 \mathrm{mg}$ artemisinin. ${ }^{8,10,12-14}$

\section{Artesunat}

Artesunat merupakan garam natrium hemisuksin ester dari artemisinin. Obat ini larut dalam air. Artesunat dapat diberikan dalam bentuk oral, rektal, IM ataupun IV. Artesunat diabsorpsi cepat, dengan kadar puncak plasma tercapai dalam 2 jam per rektal, 1,5 jam per oral dan 30 menit per IM. Hampir seluruhnya dikonversi menjadi dihidroartemisinin sebagai bentuk metabolit aktif. Eliminasinya cepat dan aktivitas sebagai anti malaria ditentukan oleh eliminasi dihidroartemisinin, dengan waktu paruh \pm 45 menit. Tidak diperlukan dosis modifikasi pada gangguan hati atau ginjal. Artesunat memiliki toksisitas yang sangat mirip dengan artemisinin.

Dosis artesunate $4 \mathrm{mg} / \mathrm{kgbb}$ sekali sehari selama 3 hari per oral dan 2,4 $\mathrm{mg} / \mathrm{kgbb} /$ dosis per IM/IV diberikan pada jam ke 0,12 dan 24 serta selanjutnya tiap 24 jam. Tiap tablet mengandung $50 \mathrm{mg}$ atau $200 \mathrm{mg}$ sodium artesunat, tiap ampul (IM/IV) mengandung $60 \mathrm{mg}$ anhidrous asam artesunaik dengan ampul terpisah 5\% larutan natrium bikarbonat dan tiap kapsul rektal mengandung $100 \mathrm{mg}$ atau $400 \mathrm{mg}$ natrium artesunat. ${ }^{8,9,15,16}$

\section{Artemeter}

Artemeter merupakan metil eter dari dihidroartemisinin, dapat diberikan per oral atau IM. Juga merupakan koformulasi dengan lumefantrin sebagai terapi kombinasi. Konsentrasi puncak plasma 
dicapai 2-3 jam setelah pemberian oral. Pada pemberian IM, absorpsi sangat bervariasi (tergantung perfusi penderita) dengan konsentrasi puncak plasma umumnya dicapai dalam 6 jam tapi bisa sampai 18 jam atau lebih pada beberapa kasus. Metabolit aktif dari Artemeter ialah dihidroartemisinin. Pada pemberian IM artemeter yang dominan, sedangkan pemberian oral dihidroartemisinin yang dominan. Biotransformasi obat ini dimediasi melalui enzim sitokrom P450 CYP3A4. Artemeter 95\% terikat dengan protein plasma. Eliminasi waktu paruh sekitar 1 jam, tapi pada pemberian IM, eliminasi bervariasi tergantung absorpsi. Tidak diperlukan dosis modifikasi pada gangguan hati atau ginjal. Toksisitas secara umum mirip dengan artemisinin. ${ }^{9,17}$

Dosis artemeter per oral yaitu 2 mg/kgbb/dosis, 2 kali sehari pada hari pertama kemudian dilanjutkan $2 \mathrm{mg} / \mathrm{kgbb}$ dosis tunggal pada 4 hari berikutnya, sedangkan injeksi dosis 1,6 mg/kgbb/dosis, 2 kali sehari pada hari pertama kemudian dilanjutkan 1,6 mg/kgbb dosis tunggal pada 4 hari berikutnya. Tersedia dalam bentuk kapsul yang mengandung $40 \mathrm{mg}$ dan $50 \mathrm{mg}$ artemeter serta ampul injeksi $40 \mathrm{mg}$ per 1 $\mathrm{ml}$ (untuk anak) dan $80 \mathrm{mg}$ per $1 \mathrm{ml}$ (untuk dewasa). Dalam sediaan kombinasi bersama lumefantrin maka tiap tablet mengandung $20 \mathrm{mg}$ artemeter dan $120 \mathrm{mg}$ lumefantrin. ${ }^{3,8,9,18}$

\section{Dihidroartemisinin}

Dihidroartemisinin merupakan bentuk metabolit aktif dari derivat artemisinin, tapi dapat diberikan per oral dan rektal sebagai sediaan tersendiri. Obat ini relatif tidak larut dalam air, dan memerlukan substansi tambahan yang tepat untuk menjamin absorpsi yang adekuat. Sediaan gabungan dengan piperakuin sementara dievaluasi kelak sebagai ACT yang menjanjikan. Dihidro-artemisinin diabsorpsi cepat pada pemberian oral dan mencapai kadar puncak plasma dalam 2,5 jam. Absorpsinya pada pemberian rektal lebih lambat, dengan pencapaian kadar puncak \pm 4 jam setelah pemberian. Obat ini berikatan dengan protein plasma sekitar 50\%. Eliminasi waktu paruhnya sekitar 45 menit melalui saluran cerna dan glukuronidasi hepatik. Toksisitasnya mirip dengan artemisinin. Setiap tablet dihidroartemisin mengandung $20 \mathrm{mg}, 60 \mathrm{mg}$ dan $80 \mathrm{mg}$ dihidroartemisinin serta tiap supositoria mengandung 80 mg dihidroartemisinin. ${ }^{9,19,20}$

\section{Artemotil}

Artemotil adalah etil eter dari artemisinin dan sangat mirip penggunaannya dengan artemeter. Absorpsi lambat dan tidak menentu, dimana beberapa pasien sukar dideteksi kadar artemotil dalam plasma hingga 24 jam setelah pemberian. Toksisitas sangat mirip dengan artemisinin. Dosis pertama $4,8 \mathrm{mg} / \mathrm{kgbb}, 6$ jam kemudian 1,6 mg/kgbb, selanjutnya 1,6 $\mathrm{mg} / \mathrm{kgbb}$ tiap hari selama 4 hari. Merupakan sediaan berbasis minyak sehingga tidak larut dalam air. Hanya diberikan secara IM dengan tiap ampul mengandung $150 \mathrm{mg}$ artemotil dalam $2 \mathrm{ml}$ larutan injeksi. ${ }^{3,4,8,18}$

\section{Aminokuinolin dan derivatnya}

\section{Primakuin}

Primakuin ialah 8-aminokuinolin dan efektif melawan bentuk intrahepatik dari seluruh tipe parasit malaria. Obat ini digunakan untuk penyembuhan radikal dari Plasmodium vivax dan ovale. Primakuin diabsorpsi di saluran cerna. Konsentrasi puncak plasma dicapai sekitar 1-2 jam setelah pemberian dan waktu paruh eliminasi 3-6 jam. Obat ini dimetabolisme secara cepat di hati. ${ }^{18,19,21}$

Efek samping terpenting ialah anemia hemolitik pada pasien dengan defisiensi G6PD, defek lain dari metabolisme glukosa melalui jalur eritrosit pentose fosfat atau tipe lain hemoglo-binopati. Sediaan berupa tablet mengandung $5 \mathrm{mg}$, 7,5 mg dan $15 \mathrm{mg}$ primakuin difosfat. ${ }^{4,18,19}$

\section{Amodiakuin}

Amodiakuin merupakan mannich base 4 aminokuinolin dengan aksi yang mirip dengan klorokuin. Obat ini diabsorpsi di 
saluran cerna dan secara cepat dikonversi di hati menjadi bentuk metabolit aktif desetilamdodiakuin, yang nantinya berefek sebagai anti malaria. Amodiakuin dan desetilamodiakuin masih terdeteksi di urin beberapa bulan setelah pemberian. ${ }^{3,4}$

Efek samping amodiakuin seperti sedikit pruritus, resiko tinggi agrnulositosis dan hepatitis derajat ringan. Dosis besar menyebabkan sinkop, spastis, konvulsi dan gerakan involunter. Sediaan berupa tablet yang mengandung $200 \mathrm{mg}$ amodiakuin base hidroklorid atau 153,1 mg klorohidrat. ${ }^{4,18,19,22}$

\section{Naftokuin}

Naftokuin ialah tetra-aminokuinolin yang diberikan sebagai kombinasi dengan artemisinin. Naftokuin memiliki struktur yang mirip dengan koenzim Q, terikat secara ireversibel dengan protein, dan bekerja dengan menghentikan maturasi dari sporozoit. $^{23}$

\section{Antimalaria golongan lain \\ Piperakuin}

Piperakuin ialah anti malaria yang merupakan sintesis pertama biskuinolin. Piperakuin lambat diabsorpsi dan waktu paruh biologik yang panjang menyebabkan piperakuin menjadi kombinasi yang baik dengan artemisinin dan derivatnya. Sejak tahun 2009 piperakuin dikombinasikan dengan dihidroartemisinin menjadi dihidroartemisinin-piperakuin (DHP) dengan angka kesembuhan $>95 \%$. Piperakuin tidak memiliki efek kardiotoksik, serta larut dalam lemak dengan distribusi yang luas dan bioavibilitas yang tetap. ${ }^{24,25}$

\section{Lumefantrin}

Lumefantrin merupakan antimalaria golongan aryl aminoalkohol termasuk kuinin, meflokuin dan halofantrin. Hanya tersedia dalam bentuk oral ko-formulasi dengan artemeter. Obat ini sangat efektif melawan multidrug resistance dari malaria falsiparum. Kadar puncak plasma dicapai 10 jam dengan eliminasi waktu paruh sekitar 3 hari. Efek samping yang timbul ringan berupa mual, nyeri kepala, pusing dan terkadang sukar dibedakan dengan gejala malaria itu sendiri. Tersedia dalam bentuk tablet yang mengandung $20 \mathrm{mg}$ artemeter dan 120 mg lumefantrin. 3,26,27

\section{Kinin}

Kinin bekerja terutama pada stadium trofozoit matur dari perkembangan parasit dan tidak mencegah sekuestrasi atau perkembangan selanjutnya stadium ring P.falciparum. Kinin juga efektif untuk terapi plasmodium malaria lainnya, namun kinin ini tidak membunuh stadium preeritrosit. $^{28,29}$ Farmakoinetik kinin diubah signifikan oleh infeksi malaria dengan mengurangi volume distribusi dan klirens obat berhubungan dengan beratnya penyakit. Konsentrasi obat pada anak $<2$ tahun dengan malaria berat adalah lebih tinggi dibandingkan anak yang lebih besar dan dewasa. Kinin diserap cepat hampir seluruhnya di saluran cerna dan mencapai kadar puncak plasma dalam 1-3 jam setelah pemberian oral. Absorpsi baik pada pemberian intramuskular untuk malaria berat. Kinin terdistribusi luas di seluruh tubuh termasuk cairan serebrospinal, ASI dan plasenta. Ekskresi meningkat di asam urin. Rata-rata eliminasi waktu paruh 11 hari pada orang sehat, 16 hari pada penderita malaria tanpa komplikasi dan 18 hari pada malaria berat. ${ }^{3,18,30}$

Penggunaan kinin menyebabkan sindrom cinchonism yang dikarakteristik oleh gejala tinitus, gangguan pendengaran, nyeri kepala, nausea, pusing dan disforia, serta kadang-kadang terjadi gangguan penglihatan. Efek samping yang terpenting ialah hipoglikemia akibat hiperinsulinemia. Pemberian secara IM berefek nyeri, nekrosis fokal dan abses serta di area endemis menyebabkan schiatic nerve palsy.

Dosis kina yang dianjurkan 30 $\mathrm{mg} / \mathrm{kgbb} /$ hari dibagi dalam 3 dosis selama 7 hari pengobatan. Sediaan dalam bentuk tablet berlapis gula berisi $220 \mathrm{mg}$ kina sulfat sedangkan kina injeksi terdiri dari ampul 2 mg berisi kina hidroklorida 25\% atau kina antipirin. $3,4,8,18,31$ 


\section{Meflokuin}

Meflokuin ialah 4 metanolkuinolin dan berhubungan dengan kinin, larut dalam alkohol dan sedikit larut dalam air. Obat ini efektif melawan segala bentuk malaria. Meflokuin diabsorpsi baik di saluran cerna tapi terdapat variasi antara individual dalam mencapai konsentrasi puncak plasma. Pemberian dosis $25 \mathrm{mg} / \mathrm{kgBB}$ dibagi dalam 2 kali dengan interval waktu 6-24 jam dapat memperbesar absorpsi dan meningkatkan toleransi. Meflokuin dimetabolisme di hati. Sekitar 98\% terikat dengan protein plasma dan didistribusikan di seluruh tubuh. Saat diberikan bersamasama artesunat, konsentrasi dalam darah meningkat, kemungkinan karena efek tidak langsung dari peningkatan absorpsi karena resolusi cepat dari gejala penyakit. Meflokuin diekskresikan sedikit di ASI. Memiliki eliminasi waktu paruh yang panjang kurang lebih 21 hari, kemungkinan karena siklus enterohepatik. Meflokuin diekskresikan di empedu dan tinja. Meflokuin diberikan peroral sebagai garam hidroklorid, tablet $250 \mathrm{mg}$ base ekuivalen dengan 274 mg garam hidroklorid. ${ }^{3,32}$

Efek samping paling sering berupa mual, muntah, nyeri perut, anoreksia, diare, kepala, pusing, kehilangan keseimbangan, disforia, somnolen dan gangguan tidur. Ditemukan gangguan neuropsikiatrik pada 1 dari 20 pasien yang menderita malaria berat yang diterapi dengan meflokuin. Efek samping yang jarang yaitu ruam kulit, pruritus, urtikaria, rambut rontok, kelemahan otot, gangguan fungsi hati, dan sangat jarang trombositopenia dan leukopenia. Terdapat peningkatan risiko aritmia jika diberikan bersama dengan beta blocker, calcium channel blocker, amiodaron, digoksin, atau antidepresan., 38,27

\section{Sulfadoksin (umumnya sudah resisten di Indonesia)}

Sulfadoksin merupakan golongan sulfonamid, yang sedikit larut di air. Sulfadoksin digunakan sebagai kombinasi tetap dengan pirimetamin dengan sediaan tablet yang mengandung $500 \mathrm{mg}$ sulfadoksin dan $25 \mathrm{mg}$ pirimetamin.
Terdapat juga sediaan injeksi yang digunakan secara IM. Konsentrasi puncak dalam darah dicapai dalam 4 jam setelah pemberian oral. Eliminasi waktu paruh terminal yaitu 4-9 hari. $^{33,34}$ Sekitar 90-95\% terikat dengan protein plasma. Obat ini terdistribusi meluas ke seluruh jaringan tubuh dan cairan, melewati sirkulasi fetal dan bisa terdeteksi di ASI. Obat ini diekskresikan lambat di urin..$^{13,33}$

Efek samping berupa reaksi alergi yang bisa menjadi berat oleh karena eliminasi obat yang lambat. Dapat terjadi mual, muntah, anoreksia dan diare. Kristaluria dapat menyebabkan nyeri lumbal, hematuri dan oligouri serta nefritis interstisial. ${ }^{3,13}$

\section{Pirimetamin (umumnya sudah resisten di Indonesia)}

Pirimetamin adalah diaminopirimidin yang digunakan sebagai kombinasi dengan sulfonamid. Efek anti malaria melalui inhibisi plasmodial dihidrofolat reduktase yang secara tidak langsung menghambat sintesis asam nukleat dari parasit. Obat ini efektif terhadap 4 jenis malaria, sekalipun resistensi telah muncul. Sediaan dalam bentuk oral dan injeksi. Pirimetamin hampir seluruhnya diabsorpsi di saluran cerna dan konsentrasi puncak plasma dicapai dalam waktu 2-6 jam sesudah pemberian oral. Konsentrasi obat terutama di ginjal, paru, hati dan limpa serta sekitar 80-90\% terikat dengan plasma protein. Waktu paruh plasma sekitar 4 hari. .,13 $^{3,13}$

Penggunaan lama dapat menyebabkan penekanan hematopoiesis berhubungan dengan penghambatan metabolisme asam folat. $^{3,4,13}$

\section{Klorokuin (umumnya sudah resisten di Indonesia)}

Dahulu sangat efektif untuk 4 spesies malaria. Klorokuin tidak berkhasiat terhadap gametosit dewasa $P$. falsiparum tetapi efektif terhadap gametosit muda spesies lain. Penyerapan klorokuin terjadi melalui usus secara cepat dan hampir sempurna kemudian ditimbun dalam jaringan khususnya hati dan sebagian kecil 
di organ yang mengandung parasit. Klorokuin mempunyai kemampuan menghalangi sintesis enzim dalam tubuh parasit dalam pembentukan DNA dan RNA. ${ }^{8}$

Efek samping klorokuin yang sering terjadi yaitu mual muntah, nyeri perut dan diare apabila klorokuin diminum dalam keadaan perut kosong. Dosis toksik klorokuin pada anak $750 \mathrm{mg}$ basa, pada dewasa $2000 \mathrm{mg}$ basa atau 30-35 mg/kgbb. Tidak ada antidotum terhadap klorokuin. ${ }^{8}$

Dosis klorokuin yang dianjurkan yaitu $10 \mathrm{mg}$ basa/kgbb/hari untuk hari pertama dan kedua, dilanjutkan $5 \mathrm{mg}$ basa/kgbb untuk hari ketiga. Tersedia dalam bentuk tablet difosfat dan sulfat. Difosfat mengandung 3 atau 5 klorokuin basa, sedangkan klorokuin sulfat mengandung 2 atau 3 klorokuin basa. Juga terdapat bentuk ampul $1 \mathrm{ml}$ dan $2 \mathrm{ml}$ larutan 8\% atau 10\% klorokuin difosfat setara dengan $80 \mathrm{mg}$ atau $100 \mathrm{mg}$ basa per $\mathrm{ml}^{8}$

\section{ACT yang beredar di Indonesia}

\section{Dihidroartemisinin-Piperakuin (DHP)}

Dosis yang digunakan yaitu dihidroartemisinin 2-4 mg/kgbb/dosis dan piperakuin 16-32 mg/kgbb/dosis, satu kali per hari selama 3 hari. Efek samping DHP hanya berupa diare ringan atau mual. Penelitian di Vietnam, Thailand dan Burma menunjukkan angka kesembuhan hampir 100\% pada pasien dengan $P$. Falciparum. Penelitian terhadap 334 penderita di Timika, Papua menunjukkan bahwa angka recrudescence pada $P$. falciparum 42 hari setelah terapi DHP hanya 2,8\%. dibandingkan $13 \%$ pada ArtesunateAmodiakuin (AAQ) dan $P$. vivax angka recrudescence 42 hari setelah terapi DHP hanya $6,7 \%$ dibandingkan $30 \%$ pada AAQ. Penelitian mendapatkan bahwa DHP sama efektif dengan artemeter lumenfantrine (AL) namun angka recrudescence pada $P$. vivax 42 hari setelah terapi DHP hanya 8\% dibandingkan $37 \%$ pada AL. ${ }^{8}$

\section{Artesunat-amodiakuin (AAQ)}

Kombinasi AAQ dengan nama dagang Artesdiaquine ${ }^{\circledR}$ atau Artesumoon ${ }^{\circledR}$ telah diedarkan disemua provinsi yang terdapat resistensi tinggi (>25\%) terhadap obat klorokuin dan sulfadoksin-pirimetamin. Dosis obat ini adalah artesunat $4 \mathrm{mg} / \mathrm{kgbb}$ sekali sehari selama 3 hari dan amodiakuin hari pertama dan hari kedua $10 \mathrm{mg} / \mathrm{kgbb}$ serta hari ketiga $5 \mathrm{mg} / \mathrm{kgbb}^{8}$

\section{Artesunat-Meflokuin}

Kombinasi artesunat diberikan selama 3 hari di Thailand. Kombinasi ini aman, ditoleransi dengan baik dan sangat efektif. Dosis pada anak yaitu artesunat $2 \mathrm{mg} / \mathrm{kgbb}$ sekali sehari selama 5 hari dimana untuk hari pertama diberikan 2 dosis dan meflokuin 15 mg meflokuin basa/kgbb dosis tunggal. $^{8}$

\section{Artemeter-Lumefantrin}

Merupakan satu-satunya kombinasi dalam bentuk fixed dose. Kombinasi aman dan ditoleransi baik pada anak-anak maupun dewasa. Absorbsi lumenfantrin meningkat bila diberikan bersama makanan. Satu tablet mengandung $20 \mathrm{mg}$ artemeter dan $120 \mathrm{mg}$ lumefantrin. Rekomendasi yang dianjurkan adalah regimen yang diberikan selama 3 hari. Obat ini diberikan pada 0, 8, 24,36, 48 dan 60 jam. Pada regimen 3 hari diberikan berdasarkan berat badan, yaitu berat badan 10-14,9 satu tablet, 15-24,9 dua tablet, 2534,9 tiga tablet dan $>35 \mathrm{~kg}$ empat tablet. Tablet diberikan 2 kali sehari selama 3 hari. Sudah tersedia dalam bentuk tablet larut dalam air dengan berbagai rasa. ${ }^{8}$

\section{Artesunat-Sulfadoksin pirimetamine}

Artesunat diberikan dengan dosis 4 $\mathrm{mg} / \mathrm{kgbb}$ sekali sehari selama 3 hari dan sulfadoksin pirimetamin dengan dosis 25 $\mathrm{mg} / \mathrm{kgbb}$ sulfadoksin dan 1,25 mg/kgbb pirimetamin dosis tunggal pada hari pertama. $^{8}$

\section{Obat malaria kombinasi non ACT di Indonesia}

\section{Kinin+doksisiklin}

Dosis kina sulfat untuk pengobatan radikal malaria falsiparum tanpa kompli- 
kasi ialah $10 \mathrm{mg} / \mathrm{kgbb} /$ dosis, 3 kali sehari selama 7 hari dikombinasikan dengan doksisiklin dosis 3-45 mg/kgbb dua kali sehari $100 \mathrm{mg}$ selama 7 hari. Doksisiklin tidak boleh diberikan pada anak di bawah usia 11 tahun. Untuk malaria berat kina diberikan dengan dosis $10 \mathrm{mg} / \mathrm{kgbb} /$ dosis dalam $500 \mathrm{ml}$ cairan dekstrosa 5\% selama 4 jam dan diulang tiap 8 jam selama minimal 48 jam. Jika pasien dapat minum obat oral, infus kina dapat diganti dengan tablet kina sulfat sampai hari ke-7.

Obat ACT yang digunakan sebagai terapi lini I malaria tanpa komplikasi yaitu DHP dan alternatif ACT bila DHP tidak tersedia yaitu artesunat lumenfantrin dan AAQ. Bila obat malaria ACT tidak tersedia dapat digunakan lini II yaitu kina+doksisiklin. ${ }^{8}$

Untuk tatalaksana malaria berat di puskesmas digunakan artemeter 3,2 $\mathrm{mg} / \mathrm{kgbb}$ IM loading dose dibagi 2 dosis (tiap 12 jam) hari pertama diikuti dengan 1,6 mg/kgbb/24 jam selama 4 hari atau di RS rujukan diberikan artesunat IV 2,4 mg/kgbb IV pada hari pertama diberikan tiap 12 jam, kemudian dilanjutkan dosis 2,4 mg/kgbb pada hari ke 2-7/24 jam (beberapa kali lebih poten dibandingkan artemeter IM). Bila obat tersebut diatas tidak tersedia dapat diberikan kina HCL dosis 10 $\mathrm{mg} / \mathrm{kgbb}$ dalam $500 \mathrm{ml}$ cairan dekstrosa 5\% selama 6-8 jam selanjutnya diberikan dengan dosis yang sama tiap 6-8 jam. ${ }^{8}$ Secara garis besar efek obat malaria dapat dilihat pada Gambar 1.

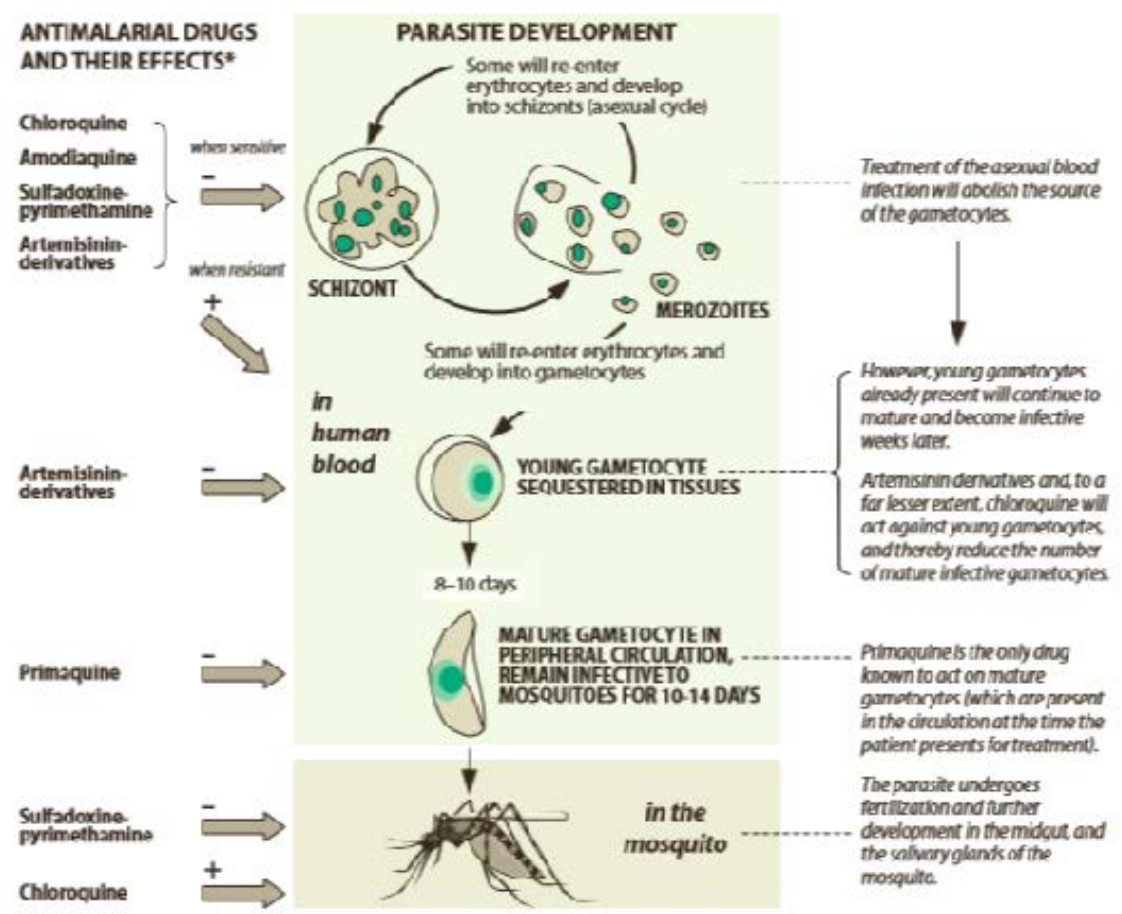

Gambar 1. Transmisi dari plasmodium dan efek obat anti malaria ${ }^{19}$

\section{SIMPULAN}

Malaria masih merupakan masalah kesehatan masyarakat di Indonesia karena masih endemis di sebagian besar wilayah Indonesia. Stratifikasi wilayah berdasarkan API menunjukkan Indonesia bagian Timur masuk dalam stratifikasi malaria tinggi, stratifikasi sedang di beberapa wilayah di Kalimantan, Sulawesi dan Sumatera sedangkan di Jawa-Bali masuk dalam stratifikasi rendah.

Meningkatnya angka kematian akibat malaria dapat disebabkan oleh perubahan lingkungan yang mengakibatkan tempat 
perindukan nyamuk semakin bertambah, diagnosis malaria yang kurang tepat dan terlambat, meningkatnya resistensi insektisida terhadap vektor, meningkatnya resistensi parasit malaria terhadap obat-obat malaria dan belum tersedianya vaksin malaria. Untuk menghadapi hal tersebut maka WHO merekomendasikan bahwa semua orang di segala usia yang secara epidemiologi tersangka malaria harus melakukan konfirmasi parasitologis diagnosis malaria baik dengan mikroskopis dan atau RDT, sehingga obat anti malaria tidak boleh dikonsumsi oleh orang dengan diagnosis klinis malaria dan obat malaria yang ada diberikan secara kombinasi untuk mencegah dan mengurangi terjadinya resistensi.

Kemkes menggunakan golongan ACT sebagai lini I malaria tanpa komplikasi yaitu DHP, AAQ atau ArtesunatLumenfantrine. Bila ACT tidak tersedia dapat digunakan lini II yaitu Kinin+ doksisiklin. Utuk terapi malaria berat digunakan Artemeter IM di puskesemas atau Artesunat IV di RS rujukan. Bila ACT tidak tersedia dapat digunakan kinin IV.

\section{DAFTAR PUSTAKA}

1. WHO Global Malaria Programme. Test, treat, track: Scaling up diagnostic testing, treat ment and surveillance for malaria. Geneva: the World Health Organization; 2012. Available from: http:// www.who.int/malaria/publications/atoz/t est_treat_track_brochure.pdf.

2. Pusat Data dan Informasi Kementerian Kesehatan RI. Epidemiologi malaria di Indonesia. Jakarta: Bul Jendela Data dan Informasi Kesehatan. 2011;1:1-16.

3. Vinetz JM, Clain J, Bounkeua V, Eastman RT, Fidock D. Chemotherapy of malaria. In: Brunton L, Chabner B, Knollman B, editors. Goodman \& Gilman's The Pharmacological Basis of Therapeutics (12th ed.) China: McGrawHill Inc, 2011; p. 70-85.

4. World malaria report 2012. Geneva: WHO, 2012.

5. Mtove G, Hendriksen IC, Amos B, Mrema H, Mandia V, Manjurano A, et al. Treatment guided by rapid diagnostic tests for malaria in Tanzanian children: safety and alternative bacterial diagnoses. Malar J. 2011;10:290.

6. Barber BE, William T, Grigg MJ, Piera K, Yeo TW, Anstey NM. Evaluation of the sensitivity of a pLDH-based and an aldolase-based rapid diagnostic test for diagnosis of uncomplicated and severe malaria caused by PCR-confirmed Plasmodium knowlesi, Plasmodium falciparum, and Plasmodium vivax. J Clin Microbiol. 2013;51(4):1118-23.

7. WHO Global Malaria Programme. WHO Policy Recommendation: Seasonal Malaria Chemoprevention (SMC) for Plasmodium falciparum malaria control in highly seasonal transmission areas of the Sahel sub-region in Africa. 2012. Available from: http://www.who.int/malaria/publications /atoz/smc_policy_recommendation_en_ 032012.pdf.

8. Rampengan TH. Malaria pada anak. Harijanto PN, Nugroho A, Gunawan CA, editors. In: Malaria dari Molekuler ke Klinis. Jakarta: EGC, 2010; p. 156-94.

9. Hombhanje FW, Huang Q. Artemisininnaphthoquine combination (ARCO ${ }^{\circledR}$ ): an overview of the progress. Pharmaceuticals. 2010;3:3581-93.

10. Lim P, Dek D, Try V, Eastman RT, Chy S, Sreng S, et al. Ex vivo susceptibility of plasmodium falciparum to antimalarial drugs in Western, Northern, and Eastern Cambodia, 2011 - 2012: association with molecular markers. Antimicrob Agents Chemother. 2013;57(11):5277-83.

11. Salman S, Page-Sharp M, Batty KT, Kose K, Griffin S, Siba PM, et al. Pharmacokinetic comparison of two piperaquine-containing artemisinin combination therapies in Papua New Guinean children with uncomplicated malaria. Antimicrob Agents Chemother. 2012;56(6):3288-97.

12. Bassat $\mathbf{Q}$, Mulenga $\mathbf{M}$, Tinto $\mathbf{H}$, Piola $\mathbf{P}$, Borrmann S, Menéndez $C$, et al. Dihydroartemisinin-piperaquine and artemether-lumefantrine for treating uncomplicated malaria in African children: a randomised, non-inferiority trial. PLoS One. 2009;4(11):e7871.

13. Thwing J, Eisele TP, Steketee RW. Protective efficacy of malaria case 
management and intermittent preventive treatment for preventing malaria mortality in children: a systematic review for the Lives Saved Tool. BMC Public Health. 2011;11(Suppl 3):S14.

14. Whegang YS, Samson A, Basco LK, Thalabard JC. Multiple treatment comparisons in a series of anti-malarial trials with an ordinal primary outcome and repeated treatment evaluations. Malar J. 2012;11:147.

15. Meremikwu MM, Odey F, Oringanje C, Oyo-Ita A, Effa E, Esu EB, et al. Open-label trial of three dosage regimens of fixed-dose combination of artemisinin and naphthoquine for treating uncomplicated falciparum malaria in Calabar, Nigeria. Malar J. 2012;11:413.

16. Tjitra E, Hasugian AR, Siswantoro H, Prasetyorini B, Ekowatiningsih R, Yusnita EA, et al. Efficacy and safety of artemisinin-naphthoquine versus dihydroartemisinin-piperaquine in adult patients with uncomplicated malaria: a multi-centre study in Indonesia. Malar J. 2012;11:153.

17. Hasugian AR, Purba HL, Kenangalem E, Wuwung RM, Ebsworth EP, Maristela R, et al. Dihydroartemisininpiperaquine versus artesunateamodiaquine: superior efficacy and posttreatment prophylaxis against multidrug-resistant plasmodium falciparum and plasmodium vivax malaria. Clin Infect Dis. 2007;44(8):1067-74.

18. Hombhanje FW, Huang Q. Artemisinin Naphthoquine Combination (ARCO ${ }^{\circledR}$ ): an overview of the progress. Pharmaceuticals. 2010, 3:3581-93.

19. Toure OA, Penali LK, Yapi JD, Ako BA, Toure W, Djerea $\mathrm{K}$, et al. A comparative, randomized clinical trial of artemisinin/naphtoquine twice daily one day versus artemether/lumefantrine six doses regimen in children and adults with uncomplicated falciparum malaria in Côte d'Ivoire. Malar J. 2009;8:148.

20. Training module on malaria control: case management (guide for tutors). Geneva: WHO, 2012.

21. Training module on malaria control: case management (guide for participants). Geneva: WHO, 2012.
22. Hombhanje FW, Linge D, Saweri A, Kuanch C, Jones R, Toraso S, et al. Artemisinin-naphthoquine combination (ARCO) therapy for uncomplicated falciparum malaria in adults of Papua New Guinea: a preliminary report on safety and efficacy. Malar J. 2009;8:196.

23. von Seidlein L, Olaosebikan R, Hendriksen IC, Lee SJ, Adedoyin OT, Agbenyega $T$, et al. Predicting the clinical outcome of severe falciparum malaria in African children: findings from a large randomized trial. Clin Infect Dis. 2012;54(8):1080-90.

24. Riccio EK, Totino PR, Pratt-Riccio LR, Ennes-Vidal V, Soares IS, Rodrigues MM, et al. Cellular and humoral immune responses against the Plasmodium vivax MSP-119 malaria vaccine candidate in individuals living in an endemic area in north-eastern Amazon region of Brazil. Malar J. 2013;12(1):326.

25. Smith GC, Sanders KC, Galappaththy GN, Rundi C, Tobgay T, Sovannaroth $\mathrm{S}$, et al. Active case detection for malaria elimination: a survey among Asia Pacific countries. Malar J. 2013;12(1):358.

26. Burrows JN, van Huijsduijnen RH, Möhrle JJ, Oeuvray C, Wells TN. Designing the next generation of medicines for malaria control and eradication. Malar J. 2013;12:187.

27. WHO. Update on artemisinin resistance April 2012. Available from: URL: http://www.who.int/malaria/publications /atoz/arupdate042012.pdf

28. Kalyango JN, Alfven T, Peterson S, Mugenyi K, Karamagi C, Rutebemberwa E. Integrated community case management of malaria and pneumonia increases prompt and appropriate treatment for pneumonia symptoms in children under five years in Eastern Uganda. Malar J. 2013;12(1):340.

29. Calderaro A, Piccolo G, Gorrini C, Rossi S, Montecchini S, Dell Anna ML, et al. Accurate identification of the six human plasmodium spp. causing imported malaria, including plasmodium ovale wallikeri and plasmodium knowlesi. Malar J. 2013;12(1):321.

30. Oladosu OO, Oyibo WA. Overdiagnosis and 
overtreatment of malaria in children that presented with fever in Lagos, Nigeria. ISRN Infectious Diseases, 2013:6.

31. Achidi EA, Apinjoh TO, Anchang-Kimbi JK, Mugri RN, Ngwai AN, Yafi CN. Severe and uncomplicated falciparum malaria in children from three regions and three ethnic groups in Cameroon: prospective study. Malar J. 2012;11:215.

32. Allen EN, Chandler CI, Mandimika N, Pace C, Mehta U, Barnes KI. Evaluating harm associated with antimalarial drugs: a survey of methods used by clinical researchers to elicit, assess and record participant-reported adverse events and related data. Malar J. 2013;12(1):325.

33. Noedl H, Se Y, Sriwichai S, Schaecher K, Teja-Isavadharm P, Smith B, et al. Artemisinin resistance in Cambodia: a clinical trial designed to address an emerging problem in South East Asia. Clin Infect Dis. 2010;51(11):e82-9.

34. Woodrow CJ, Haynes RK, Krishna S. Artemisinins. Postgrad Med J. 2005;81(952):71-8. 